\title{
LAW AND LITERATURE - THE CONTRIBUTION OF LORD DENNING
}

\author{
Sir Martin Nourse*
}

At the beginning of the $21^{\text {st }}$ century an audience consisting mainly of lawyers will not need to be persuaded that the law has a contribution to make to literature or, at any rate, that it has a literature of its own. A hundred years ago it might have been different. The Oxford Book of English Prose, published in 1925, contained extracts from only three reported judgments. By a coincidence, it was in the Yale Review of the same year that Benjamin Cardozo's Law and Literature first appeared, since when the opinion has been growing, certainly amongst lawyers, that there must be something in it.

For myself, the defining moment was the publication in 1965 of Louis BlomCooper's The Literature of the Law. ${ }^{1}$ More that thirty-five years later, in his Margaret Howard Memorial Lecture entitled Judges among the Literati at Oxford in 2001 Sir Louis confessed to being unashamedly an anthologist of legal writings. If an element of self-deprecation is here to be detected, I would altogether reject it. To be in the company of such as Palgrave and Wavell is a cause for pride, especially where the sources are so diverse and largely unavailable to the average reader. I read every word of The Literature of the Law, almost at one sitting. Lord Birkett's forward is itself a work of literature, reminding us that it is not only judges who have contributed, but great advocates like John Somers and Thomas Erskine. Here is what Macaulay said of Somers, later Lord Chancellor under William III, as junior counsel for the Seven Bishops in 1688, the greatest constitutional trial in our history:

"Somers rose last. He spoke little more than five minutes; but every word was full of weighty matter; and when he sate down his reputation as an orator and a constitutional lawyer was established.”

But just as the art of the great conversationalists survives only through the pens of their contemporaries, and then only if they have a Boswell to record them, so advocacy survives on in the record of the reporter. While advocacy so recorded may itself be literature, the record lacks the voice, the gesture and deportment which contributed to its greatness. Not so the report of a judgment which, though its delivery may often have impressed and persuaded, is primarily

* Former Lord Justice of Appeal, former Vice-President, Court of Appeal (Civil Division), Acting Master of the Rolls, 2000.

${ }^{1}$ (New York: Macmillan, 1965). 
intended to be read. For this reason, when we refer to the literature of the law, we think mainly of those judgments which, by reason of their structure, style and language, can justly be regarded as literary compositions.

The notion that judgments ought to be of literary value was regularly articulated by Lord Campbell in his Lives of the Lord Chancellors ${ }^{2}$ published in the 1840's. In assessing their judicial qualities, at any rate of those who held office from the $17^{\text {th }}$ century onwards, he invariably commented on their literary gifts or lack of them. His greatest scorn was reserved for Lord Eldon. While Campbell did not hesitate to place him, as a judge, above all the judges of his own time, acknowledging that "for law he really had a natural genius, which was improved by long, sever, and unwearied discipline”, he said of his neglect of literature:

“As a misfortune to Lord Eldon's judicial reputation, I must likewise point out his utter relinquishment of literature, from the time when he began to study the law.... I do not now speak of his loss of that caste to which the Somersets, the Cowpers and the Talbots, the companions of Swift, Addison and Pope, had belonged - not to his neglect of fame - but the deprivation of taste which he displayed. Having forgotten his modicum of classical lore, and remaining wholly unacquainted with modern authors, he had no images in his mind, and no turns of phraseology, beyond what he picked up for perusing deeds and equity reports. In his latter days he could neither speak nor write grammatically - in so much that people would not believe he had gained a prize at Oxford for English composition; and he was actually compared to the roué Duke of Orleans, who said of spelling 'we quarrelled at the outset of life, and never made up our differences'. This vandalism impaired not only the grace but the efficiency of his high judicial qualities, and not only deprived him of the benefit of knowing something of public opinion and of the progress of improvement, but really hindered him from arranging and expressing his thoughts so as to do justice to the right conclusions at which he had arrived. The celebrity of Lord Mansfield and Lord Stowell, as judges, is in no small degree owing to their having continued to refresh and to embellish their professional labours by perusing the immortal productions of poets, historians and moralists.”

2 (London: John Murray, 1868). 
This effusion notwithstanding, it is reassuring to record that later in his life of Lord Eldon, Lord Campbell said: "it is much better, if they cannot unite, that a judge should have law without literature, than literature without law."

Since Lord Campbell wrote there has been a steady stream of English-speaking judges, though a minority of judges as a whole, who have embellished their judgments with a distinctive and attractive style, not usually ornate, that entitles them to rank as literature. In order to show that Lord Denning was not the only star in the literary firmament of his time, I will mention another name from the second half of the $20^{\text {th }}$ Century, whose inclusion in that number would not be denied. I speak of Lord Justice Harman. He was five years older that Lord Denning, a classical and not a mathematical scholar, an equity rather than a common lawyer. He sat in the Court of Appeal throughout the 1960's.

In 1957 Mr Justice Harman had to construe the will of George Bernard Shaw. The opening of his judgment was immediately recognised as a classic of its kind. I do not apologise for reading it again. Those of you who know it will certainly enjoy hearing it again. Those of you who do not will certainly enjoy hearing it for the first time:

"All his long life Bernard Shaw was and indefatigable reformer. He was already well known when the present century dawned, as a novelist, critic, pamphleteer, playwright and during the ensuing half-century he continued to act as a kind of itching powder to the British public, to the English-speaking peoples, and, indeed to an even wider audience, castigating their follies, their foibles and their fallacies, and bombarding them with a combination of paradox and wit that earned him in the course of years the status of an oracle: the Shavian oracle; and the rare distinction of adding a word to the language. Many of his projects he lived to see gain acceptance and carried into effect and become normal. It was natural that he should be interested in English orthography and pronunciation. These are obvious targets for the reformer. It is as difficult for the native to defend the one as it is for the foreigner to compass the other. The evidence shows that Shaw had for many years been interested in the subject. Perhaps his best known excursion in this field is Pygmalion, in which the protagonist is a professor of phonetics: this was produced as a play in 1914 and has held the stage ever since and invaded the world of the film. It is, indeed, a curious reflection that this same work, tagged with versicles which I suppose Shaw would have detested, and tricked out with music he would have 
eschewed (see the preface to The Admirable Bashville), ${ }^{3}$ is now charming huge audiences on the other side of the Atlantic and has given birth to the present proceedings. I am told that the receipts from this source have enabled the executor to get on terms with the existing death duties payable on the estate, thus bringing the interpretation of the will into the realm of practical politics.The testator, whatever his other qualifications, was the master of a pellucid style, and the reader embarks on his will confident of finding no difficulty in understanding the objects which the testator had in mind. This document, moreover, was evidently originally the work of a skilled equity draftsman. As such I doubt not it was easily to be understood if not of the vulgar at any rate by the initiate. Unfortunately the will bears ample internal evidence of being in part the testator's own work. The two styles, as ever, make an unfortunate mixture. It is always a marriage of incompatibles: the delicate testamentary machinery devised by the conveyancer can but suffer when subjected to the cacoethes scribendi of the author, even though the latter's language, if stood alone, might be a literary masterpiece.This will is a long and complicated document made on June 12, 1950, when the testator was already ninety-four years old, though it is fair to say that it is rather youthful exuberance that the circumspection of old age that mars its symmetry."

Sir Louis Blom-Cooper has described Lord Justice Harman as the exponent of the pithy and elegant extempore judgment. As an example and a link between him and Lord Denning, I read an extract from another of Lord Justice Harman's judgments included in Sir Louis' anthology, Campbell Discount Ltd v Bridge, ${ }^{4}$ though I suspect that this may have been what is know in the Court of Appeal as and overnight judgment:

"I am of the same opinion and though I should like to emulate the laconic terms of the judgment of the county court judge which was expressed in two words, I feel constrained to add a word or two because of the uneasy feeling I have that the position of the law as it stands is not satisfactory... The solution may be that the minority view in Cooden Engineering was in fact the right one. I do not think anyhow that the discrepancy can

\footnotetext{
${ }^{3}$ (Murrieta, California: Classic Books, 2001).

${ }^{4}$ [1961] 1 QB 445.
} 


\section{THE DENNING LAW JOURNAL}

be healed by some rather loose conception of what are called equitable principles. Equitable principles are, I think, perhaps rather too often bandied about in common law courts as though the Chancellor still had only the length of his own foot to measure when coming to a conclusion. Since the time of Lord Eldon the system of equity for good or evil has been a very precise one and equitable jurisdiction is exercised only on wellknown principles. There are some who would have it otherwise, and I think Lord Denning is one of them. He, it will be remembered, invented an equity call the equity of the deserted wife. That distressful female's condition has really not been improved at all now that this so-called equity has been analysed.”

That I believe is how the judgment was delivered, though if you look in the Law Reports, you will find that the references to Lord Denning and the deserted wife's equity have been omitted on revision.

Turning to Lord Denning himself, it is necessary to remind ourselves of the bare bones of his judicial career. He was appointed a judge of the Probate Divorce and Admiralty Division in 1944, being transferred to the Kings Bench Division in October 1945. During his time there he was the judge nominated to hear appeals from pensions appeal tribunals. In October 1948 he became a lord justice of appeal, an office he held until April 1957, when he was appointed a lord of appeal in ordinary. Five years later, in April 1962, he returned to the Court of Appeal as Master of the Rolls, an office which he held until July 1982.

In judging Lord Denning's contribution to the literature of the law, it is necessary to distinguish between the periods 1944 to 1962 and 1962 to 1982 . By and large there is a noticeable contrast between the style of his judgments in the first period, especially when he was a lord justice, and the style of his judgments in the second, when he was Master of the Rolls. In Lord Denning, the Man and his Times, a contribution by the late Professor Heuston to Lord Denning: the Judge and the Law, ${ }^{5}$ it is said of the first period:

"If the reader of the law reports had not already realised it, there were now many signs of a powerful new mind at work. In many ways the judgments of the fifties are classic Denning; there is still enough respect for the precedent, for the analysis of the cases to be full and careful, and the style, clear and vivid, is not yet marred by the self-conscious tricks of the Seventies. Everyone who remembers those days will have his own

\footnotetext{
${ }^{5}$ J L Jowell and J P W B MacAuslan (London: Sweet and Maxwell, 1984).
} 


\section{THE DENNING LAW JOURNAL}

recollections of how he reacted to the masterly line of judgments.”

Of the second period Professor Heuston said:

"Denning's style had always been unusual; by the mid-seventies it was not quite so admired as it had been. The structure of the judgment was as clear and sound as ever, and often praised by his fellow judges, but a certain striving after effect has become noticeable in the style rather than in the arrangement. There were few or no subordinate clauses, and sometimes no verb in the sentences. So the style was lacking in the cadences. Also in the terse vivid opening sentence, to which he himself attached so much importance for gripping the reader's attention, often seemed inappropriate, especially in cases of severe personal injuries. Parodies began to appear - sometimes quite amusing.”

In a footnote reference is made to Grenouille $v$ National Union of Seamen (1979), which you will find fully reported in the Family Story. ${ }^{6}$

Other, more recent, commentators have offered similar criticisms of Lord Denning's later style. In his Margaret Howard Memorial Lecture Sir Louis BlomCooper said, in a section dealing with the colloquial style of the judgment:

"No one better exemplifies this category than Lord Denning whose idiosyncratic style was in fact unique. His penchant for beginning every (well, nearly every) judgment with a simple story had the commendable virtue of appealing to a wide audience, but it tended to grate on the professional ear, at least when delivered orally in court, and even later in written form. This form of judgment was meretricious, in the sense of being showily but falsely attractive."

In The Form and Language of Judicial Opinions, a lecture delivered to the annual conference of the Society of Public Teachers of Law at Glasgow University in 2001, Lord Roger of Earlsferry said:

"Lord Denning is, of course, a subject in himself but not one to be embarked upon here. I shall only say that the famous openings, though great fun, do not, in my view, really work. They strike me as faux naïf - something like the literary

\footnotetext{
${ }^{6}$ (London: Hamlyn, 1982).
} 
equivalent of the primitive paintings of Grandma Moses. But Grandma Moses was not an educated woman, whereas Lord Denning was a clever and highly educated man. No one ever spoke as Lord Denning wrote in these passages and no one ever wrote in that way except in fairy stories and tales for children. The style is so contrived that it alerts the reader to the fact that something is afoot"

In a footnote Lord Rodger says that the famous openings are and example of what linguistic scholars call "foregrounding".

I return to the first period. The earliest judgment in which a foretaste of the later style has been detected is James $v$ Minister of Pensions, ${ }^{7}$ an appeal from a decision of a pensions appeal tribunal, where Mr Justice Denning said:

\begin{abstract}
"Gunner James joined the army on July 24, 1941, at the age of thirty-two. In January 1943, he had a swelling on the right side of his neck which gradually spread. He was sent to hospital, when a diagnosis of Hodgkin's disease was made. In April 1943 he was discharged on account of it. He claimed a pension. It was rejected by the Minister. In February 1946 he died on account of the disease. His widow claimed a pension. Her claim was also rejected by the Minister. She appealed to a tribunal who, on September 18, 1946, rejected her appeal. She did not apply to the tribunal for leave to appeal within the six weeks allowed by the rules of the tribunal. On November 21, 1946, the case of Donovan v Minister of Pensions, [(1946), not reported], which was also a case of Hodgkin's disease, was decided in favour of the widow. When knowledge of this decision came to Mrs James's advisers they sought from the tribunal leave to appeal out of time. The tribunal itself and the President of the Pensions Appeal Tribunals refused the application, refusing to extend the time or to grant leave. The widow now applies for leave to appeal.”
\end{abstract}

It will not surprise you to hear that she got it. In the Family Story Lord Denning says that the effect of this decision was magical; many men obtained pensions which had previously been refused. He described the pensions appeals as perhaps the most rewarding series of cases in his career, pointing out, it could be said with more than satisfaction, that he was the sole judge - and what was

${ }^{7}$ [1947] KB 876. 
more, a judge from whose decision there was no appeal to the Court of Appeal or anyone else.

For knowledge of the judgment in James $v$ Minister of Pensions and for much else which follows I am indebted to an article entitled It all started with Gunner James by Cameron Harvey of the University of Manitoba, first published in 1983 Gazette of the Law Society of Upper Canada and reprinted in the Denning Law Journal for 1986. The author said that this judgment, though not entirely in the classic Denning style, was the seminal judgment. For myself, I would describe it as a classic example of the first period of Lord Denning's judgments.

The first judgment of Lord Justice Denning to be found in the Law Reports is Bishopsgate Motor Finance Company Ltd v Transport Brakes Ltd, ${ }^{8}$ a case about the sale of goods in market overt. He started his judgment thus:

"I agree. In the development of our law, two principles have striven for mastery. The first is for the protection of property: no one can give a better title than he himself possesses. The second is for the protection of commercial transactions: the person who takes in good faith and for value without notice should get a good title. The first principle has held sway for a long time, but it has been modified by the common law itself and by statute so as to meet the needs of our own times. The modification here in question is one conferred by the common law itself."

What Professor Heuston described as the "masterly line of judgments" had begun. When you get to the second volume of the King's Bench reports for 1949 you find them coming one after another. They include Seaford Court Estates Ltd $v$ Asher, ${ }^{9}$ one of Lord Denning's earliest decisions on the construction of statutes. He said:

"Whenever a statute comes up for consideration it must be remembered that it is not within human powers to foresee the manifold sets of facts which may arise, and, even if it were, it is not possible for them in terms free from all ambiguity. The English language is not an instrument of mathematical precision. Our literature would be much the poorer if it were. This is where the draftsmen of Acts of Parliament have often been unfairly criticised. A judge, believing himself to be fettered by the supposed rule that he mist look to the language and nothing else,

\footnotetext{
${ }^{8}[1949] 1 \mathrm{~KB} 322$.

${ }^{9}$ [1949] 2 KB 481.
} 
laments that the draftsmen have not provided for this or that, or have been guilty of some or other ambiguity. It would certainly save the judges trouble if Acts of Parliament were drafted with divine prescience and perfect clarity. In the absence of it, when a defect appears a judge cannot simply fold his hands and blame the draftsmen. He must set to work on the constructive task of finding the intention of Parliament, and he must do this not only from the language of the statute, but also from a consideration of the social conditions which gives rise to it, and of the mischief which is was passed to remedy, and then he must supplement the written word so as to give 'force and life' to the intention of the legislature..... Put into homely metaphor it is this: A judge should ask himself the question: If the makers of the Act had themselves come across this ruck in the texture of it, how would they have straightened it out? He must then do as they would have done. A judge must not alter the material of which it is woven, but he can and should iron out the creases.”

Perhaps best of all from this volume and the very next decision reported is Smith and Snipes Farm Ltd v River Douglas Catchment Board, ${ }^{10}$ the earliest case in which Lord Denning propounded is view that a person may enforce an agreement respecting property made for his benefit, although he is not a party to it. His judgment begins thus:

"There is in Lancashire a river called Eller Brook which is liable to overflow its banks and the flood the adjoining land. In 1938, in order to prevent the flooding, eleven owners of the land through which the river ran made an agreement with the local catchment board, whereby the board undertook to widen, deepen and make good the banks of the river, and thereafter to maintain them, and the landowners paid a contribution towards the cost. The Board did the work and practically completed it by 1940 , but they did it so unskilfully that, in the opinion of experts, it was from the first doomed to failure. The landowners, of course, did not know this and set about cultivating the land. The low meadows, which had been rough marshland, were broken up and brought under the plough. Crops were sown and harvested. But the banks of the river were not strong enough to stand serious floods. In 1944 they burst. The breach on that occasion was soon closed, but the board's engineer was unaware of the danger. He

${ }^{10}[1949] 2$ KB 500. 


\section{THE DENNING LAW JOURNAL}

reported to the board that 'the bank is a bad one under any conditions'. In 1945 there was another burst near by, and he reported that 'this bank is largely composed of sand. I propose to put a machine on to strengthen it as soon as one is available'. But apparently he did nothing, or at any rate nothing effective. The landowners and their tenants went on cultivating the land. They did not know that the banks were doomed failure. Then in 1946 the worst happened. Serious floods arose, the banks burst, the fields were flooded, and the crops ruined. This action is brought by a tenant of the fields against the board to recover the value of the crops he has lost. The present owner joins in the action, claiming his loss of rent, but the substantial claim is by the tenant company. On those facts it is my opinion that the board broke their contract. It was an implied term that they should do the work with reasonable care and skill so as to make the banks reasonably fit for the purpose of preventing flooding."

It is difficult not to think of that as a model of its kind. Not only does it tell you, in little more than a paragraph, what the case is all about and the judge's view of it is. It does so in the clear and vivid style admired by Professor Heuston and with a countryman's feeling for the land. The style is about as far from being staccato as it is possible to be. It is fluid, indeed mellifluous. I have always regarded it as judicial prose of the highest order.

There is much to be said for the view that Lord Denning felt most at home in cases with a country setting. One of his first recorded dissents was in Wright $v$ Callwood, ${ }^{11}$ a case where the county court judge had held that the defendant had been negligent in driving calves on to a road. The majority of the Court of Appeal disagreed. But Lord Justice Denning thought that the judge had been right. He said:

"The plaintiff was riding her bicycle, quite carefully, along a road from Nantwich to Audlem. As she came opposite a gate leading to a farmyard, two calves rushed out, one of them knocked her off her bicycle, and she was injured. She brings this action against the farmer for damages. The calves had been in the field on the other side of the road, and the farmer had gone to fetch them by himself without the help of anyone else. He had driven them out of the field and along the public highway and into the drive leading towards the farmyard. As they were going along the drive, which is only fifty feet long, suddenly a motor

${ }^{11}$ [1950] 2 KB 515. 
lorry in the farmyard started up. The two calves were frightened and dashed back down the drive with the farmer following them. Hence the accident. The question is whether the plaintiff can recover."

As the 1950's went on, the style remained clear and vivid, subordinate clauses were note eschewed and every sentence had a verb. But it is possible to trace a development during those years from the mellifluous prose of Smith and Snipes Hall Farm towards the staccato style of the 1960's and 1970's. Thus in Deeble v Robinson: ${ }^{12}$

"Mr Deeble has a milk round. He sells milk to people at the doors of their houses. He runs his business from a dairy building where he keeps his equipment, refrigerator, spare milk bottles, and so forth, and a stable where he keeps his horse and float. His round is seven streets adjoining the premises. He does not actually have a shop as ordinarily understood. His lease of these premises is coming to an end, and he wants to stay on there. This depends on whether the premises come within the definition of a 'shop' in the Leasehold Property (Temporary Provisions) Act 1951."

This, I am sure you will agree looks forward to Beswick v Beswick ${ }^{13}$ in 1966. Again, in Rands v McNeil: ${ }^{14}$

"A Yorkshire farmer had a dangerous bull. He knew it was dangerous because the bull on one occasion had chased one of his men in the yard. The farmer thereafter kept the bull inside a loose box all of the time. It was kept there untethered. On a later occasion the bull got the farmer himself against the wall of the box and the farmer then took his horns off. The bull was never let out of the box except when the box has to be cleaned out. Even the cows were taken into the box for service."

Then in Slater v Clay Cross Co Ltd: ${ }^{15}$

${ }^{12}$ [1954] 1 QB 77.

13 [1966] Ch 538.

14 [1955] 1 QB 253.

15 [1956] 2 QB 264. 


\section{THE DENNING LAW JOURNAL}

"In Derbyshire there has been for well over a hundred years a railway line owned by the Clay Cross Co. We were told that George Stephenson himself made it. The company use it to carry limestone from their quarries at Crich down to Ambergate. It is a small gauge line, only 3 feet 3 inches wide, and is two and a half miles long. On that small line there are two tunnels. One of them, with which we are concerned, is only 8 or 9 feet high and it is just 66 yards long. On February 12, 1953, the plaintiff was walking through the tunnel when she suddenly realised that a train was coming up behind her. She got down on the ground to seek what safety she could but unfortunately the train ran over one of her legs.... She now claims damages against the Clay Cross Co., saying that it was their fault."

The early 1950's were exciting times. Professor Heuston has rightly said that everyone who remembers them will have his own recollections of how he reacted. Permit me therefore a personal recollection. Between 1953 and 1955 I was reading law at Cambridge. By that time the dons were up in arms at many of Lord Denning's judgments, especially his dissents. Not so the students. I remember us passing messages round at the back of the lectures saying such as: "Have you read in the Times today and seen the latest judgment of hero Denning, LJ?” One Friday evening in February 1955 he came down to address the Law Society. I have his letter of acceptance still. I remember taking him into the largest room in the Old Schools, packed out to the limits, almost literally to the extent of people hanging on the rafters. I opened proceedings by saying that to introduce Lord Justice Denning to an audience such as that was rather like going onto the balcony at St Peters, Rome and introducing the Pope. Of course it was an outstanding piece of nerve, which only a student could have perpetrated. But the audience seemed to love it and the speaker himself did not demur.

Before turning to the second period, I must remind you of two passages from Lord Denning's books in which he spoke about himself. First, from The Discipline of Law: ${ }^{16}$

"At Oxford I studied Mathematics. No need for words there. The tools I used then were numbers, letters and symbols. They were lifeless things without meaning or sound - necessary tools of the scientist but not of the lawyer. But when I was called to the Bar, I had to become proficient with words. I did it by drawing on my reserves of English literature. These I had acquired at the Elizabethan Grammar School to which I went daily. I had read

${ }^{16}$ (London: LexisNexis Butterworths, 1979). 


\section{THE DENNING LAW JOURNAL}

much of Shakespeare and many of our poets and novelists while still at school. All my prizes from the age of 11 were for English. I have them still, bound in handsome leather, with the school crest and the date AD 1569. The titles in succession are the Great Authors, Macaulay, Carlyle and Milton. Reading these and others provided the essentials: a wide vocabulary of words, and understanding of the meaning attached to them by the masters of the language..... Next I had to practise continually. As a pianist practises the piano, so the lawyer should practise the use of words, both in writing and by word of mouth..... In chambers, if asked to advise, I took infinite pains in the writing of an opinion. I crossed out sentence after sentence. I wrote them again and again.”

We can be certain that when he came to write his reserved judgments in later life Lord Denning still crossed out sentence after sentence and wrote them again an again. I was once told by his faithful court reporter, Miss Mavis Hill, that the transcripts of his extempore judgments came back to her heavily amended, so as to improve the style. Undoubtedly, many of his judgments were works of conscious artistry. In his later years the artistry sometimes appeared to be selfconscious.

Next, I read a well-known passage from the Family Story, where he describes "the usual kind" and then "my kind" of judgment:

"I start my judgment, as it were, with a prologue - as the chorus does in one of Shakespeare's plays - to introduce the story. Then I go on from act to act as Shakespeare does - each with its scenes - drawn from real life. But I do it by subdividing my judgment up into main headings (corresponding to the acts) and sub-paragraphs (corresponding to the scenes) - each with a caption - so as to catch the eye. I draw the characters as they truly are - using their real names - so that I never get them mixed up. Never plaintiff or defendant, or appellant or respondent. In telling the story, I set out the merits - I rely on them - I do not scorn them. Because the merits go to show where the justice lies. I use every argument that appears to me to be valid. I am not afraid of the rebuke, 'That is mere prejudice': for I know that only too often it is used only as a way of escape from the merits. I avoid long sentences like the plague: because they lead to obscurity. It is no good if the hearer cannot follow them. I strive at all costs to be clear. Not ambiguous or prevaricating. I refer sometimes to previous authorities - I have 


\section{THE DENNING LAW JOURNAL}

to do so - because I know that people are prone not to accept my views unless they have support from the books. But never at much length. Only a sentence or two. I avoid all reference to pleadings and orders - unless something turns on them. They are merely lawyer's stuff. They are unintelligible to anyone else. I finish with a conclusion - an epilogue - again as the chorus does in Shakespeare. In it I gather the threads together and given the result.”

This passage can be objected to on two grounds: first, the grandiose comparison with Shakespeare; second, the implication that "my kind" of judgment is the only kind that is any good. It is important to remember that it was written in 1981, when the author can only have been thinking of later judgments. Many of the most famous of these are referred to in It All Started with Gunner James, where Cameron Harvey speaks of the impressive array of "openers", grouping them into nine categories (I will give and example of each): the intriguing opener ("It all started in a public house"); the historical opener ("Today we look back far in time to a town or village green."); the fatal and deadly opener ("A man"s head got caught in a propeller. He was decapitated and killed."); the "This is the case" opener ("This is the case of three smugglers"); the editorial opener ("Counsel for the vendor referred to this case as a comedy of errors. It is no comedy but a history of errors."); the non sequitur opener ("Many years ago Sir Edward Coke had a case about six carpenters. Now we have a case about six car-hire drivers."); the "This is an interesting case" opener ("This is a short but fortunately a very rare point"); the whimsical opener ("A gigantic ship was used for a gigantic fraud.") the picturesque opener ("In summertime village cricket is the delight of everyone. Nearly every village has its own cricket field where the young men play and the old men watch.”)

This brings me to Lord Denning's old folks. I read from Cameron Harvey’s article:

\footnotetext{
“There was old Herbert Bundy of Yew Tree Farm, Old Mr Baker of Dunsmore in Buckinghamshire, old Mrs Millward whose will was contested, old Mrs Annie Levenson who had one of the best pitches in the Petticoat Street Market in London, and old $\mathrm{Mr}$ Jones the scrap merchant. But his most memorable work sketch was none other than old Peter Beswick.”
}

The earliest reference I have found to one of the old folks is not in a Denning judgment; it is to "old Caleb Diplock" in a lecture entitled "The Changing Civil Law" delivered in about 1953. He it was, you will remember, who directed his executors to apply the residue of his large estate for such charitable or benevolent 


\section{THE DENNING LAW JOURNAL}

object of objects as they should in their absolute discretion select. Because he had used the word "or" instead of "and", it was held by the Court of Appeal and the House of Lords, much to the disgust of Lord Denning, that the gift, not being exclusively charitable, was void for uncertainty and, later, that the charities who, in all innocence, had received distributions from the estate must repay them for the benefit of the next-of-kin.

It is not possible within the compass of a piece such as this to quote more fully from the later judgments. On the whole they are better known than the earlier ones and many of you will have your own favourites. The narrative introduction to Broome $v$ Casse ${ }^{17}{ }^{17}$ is of the highest quality. Not is it possible to quote further from the books, the lectures and the Profumo Report of 1963, in which Lord Denning took a justifiable pride. I will only say that The Family Story contains passages of deep poignancy telling of the deaths of his brothers Jack and Gordon during the Great War and his first wife, Mary, in 1941. Had he written often thus, it would have been vain to blame, and useless to praise him.

In literary criticism the contributions of those who have themselves been creative writers (Coleridge and Eliot are names that spring to mind) have been of special value, not just for their intuitive judgments of others but as an insight into their own compositions. I want to end with a brief consideration of Lord Denning's own literary tastes, so far as we can gather from the man and what he has left behind. In that way we may be able to make a surer assessment of his contribution to the literature of the law.

As we have heard, he read much of Shakespeare and many of our poets and novelist whilst still at school. It seem likely that his tastes were settled by the time he went off to the Great War, at any rate by the time he left Oxford. The Bible and Shakespeare apart, he has told us of Macaulay, Carlyle and Milton. Much of the rest must be guesswork, both from the authors he quotes or refers to and those he does not. Chaucer he certainly admired, Bacon and Bunyan. He does not mention Spenser or any of the Elizabethan dramatists other than Shakespeare, nor Donne (as a poet) or any of the metaphysical poets, nor Marvell or Dryden, nor in the next century, Pope or Cowper. In The Family Story he says, surprisingly, that to him Johnsons's prose, poetry and philosophy are turgid and unreadable. Boswell, however, is a favourite. Gray he mentions, but not Goldsmith. He does not mention any of the eighteenth century novelists, though I suspect that, like Lord Birkett, he would have admired their prose, Sterne particularly.

When we get to the next century, Wordsworth is a favourite among the Romantic poets, not Byron or Shelley, I would think, perhaps not even Keats or Coleridge. Dickens seems to have been his favourite Victorian novelist and Tennyson and Browning his favourite poets. I doubt he would have had any time

${ }^{17}[1971] 2$ QB 354. 


\section{THE DENNING LAW JOURNAL}

for Swinburne. Among the minors, he liked Blunt, Clough and Christina Rossetti and, on a lighter note, WS Gilbert and Lewis Carroll. Moving into the twentieth century Kipling, Binyon, Blundon and Brooke were favourites. No doubt Julian Grenfell would have been too, though not, it seems, Owen or Sassoon. He does not mention Masefield.

Standing back at this point, we could say that Lord Denning's tastes in literature were those of a conventional, educated Englishman born at the end of the nineteenth century. On Desert Island Discs he chose Palgrave's Golden Treasury as the book to take with him. Knowing what we do of his character and high morality, we can understand that he would not have felt comfortable with the poetry of Byron Shelley, or Swinburne, of each of whom, as an individual, he probably disapproved. But I think it goes further than that. Knowing of his affection for Milton and Tennyson, in whose verse the senses of sight and hearing are so pronounced, though not for the less intellectual senses of smell, taste and touch, and assuming, as I have, that he was not move by poets such as Keats, I think we would have to say that his sensibility, though by no means defective, was limited. It must be significant that in the Family Story he said that he had no ear for classical music.

It must also be said that he never caught up with what were then called the modernist poets, whose reputations were established before he was forty: Eliot, Auden, Spender, Day Lewis, MacNeice. Perhaps that was an opportunity missed. Take Hinz $v$ Berry ${ }^{18}$ where there is one of his most famous openers: "It happened on April 19, 1964. It was bluebell time in Kent." Suppose he had added; "April is the cruellest month.” True, we would have been mightily surprised, but gratified as well. Finally, it must be said that the whole of European literature appears to have been to him a closed book.

It is a matter of little import that we should have to conclude that Lord Denning's tastes in literature were conventional, even ordinary. A cultivated, far less a refined taste, has never been an essential of literary composition. More important are imagination and originality. These he certainly had. In a letter to his brother Jack at the front in 1916 he promised to send him one of his lately composed poems. I am not aware that he left any verse behind him. It is difficult to think of him as a poet. But he did have a poetico-dramatic imagination which conjured the settings for his judgments and vivified the players as he, not always others, saw them. As we who remember him so well pass on, I think the later judgments will cease to grate even on the professional ear and the style of fairy stories and tales for children will enlarge their appeal to a more general readership. The superb prose of the earlier judgments, of which I have sought to remind you, must always be admired.

${ }^{18}[1970] 2$ QB 40. 
If the great end of literary endeavour is to excite the intellect and enthuse the heart, that test is passed. Remember that the judgment, though it can be an art form, will always be a minor form, such is the straight-jacket in which it is written. Even if the judgments of Lord Denning the fancy does not roam at will. Perhaps his greatest literary achievement is sometimes to charm his readers into thinking it does. 